\title{
Babesia spp. in ticks and wildlife in different habitat types of Slovakia
}

Zuzana Hamšíková1, Mária Kazimírová ${ }^{*}$, Danka Haruštiakováa', Lenka Mahríková1, Mirko Slovák1, Lenka Berthová ${ }^{3}$ Elena Kocianová ${ }^{3}$ and Leonhard Schnittger ${ }^{4,5}$

\begin{abstract}
Background: Babesiosis is an emerging and potentially zoonotic disease caused by tick-borne piroplasmids of the Babesia genus. New genetic variants of piroplasmids with unknown associations to vectors and hosts are recognized. Data on the occurrence of Babesia spp. in ticks and wildlife widen the knowledge on the geographical distribution and circulation of piroplasmids in natural foci. Questing and rodent-attached ticks, rodents, and birds were screened for the presence of Babesia-specific DNA using molecular methods. Spatial and temporal differences of Babesia spp. prevalence in ticks and rodents from two contrasting habitats of Slovakia with sympatric occurrence of Ixodes ricinus and Haemaphysalis concinna ticks and co-infections of Candidatus N. mikurensis and Anaplasma phagocytophilum were investigated.
\end{abstract}

Results: Babesia spp. were detected in $1.5 \%$ and $6.6 \%$ of questing I. ricinus and $H$. concinna, respectively. Prevalence of Babesia-infected I. ricinus was higher in a natural than an urban/suburban habitat. Phylogenetic analysis showed that Babesia spp. from I. ricinus clustered with Babesia microti, Babesia venatorum, Babesia canis, Babesia capreoli/Babesia divergens, and Babesia odocoilei. Babesia spp. amplified from H. concinna segregated into two monophyletic clades, designated Babesia sp. 1 (Eurasia) and Babesia sp. 2 (Eurasia), each of which represents a yet undescribed novel species. The prevalence of infection in rodents (with Apodemus flavicollis and Myodes glareolus prevailing) with B. microti was $1.3 \%$ in an urban/suburban and $4.2 \%$ in a natural habitat. The majority of infected rodents (81.3\%) were positive for spleen and blood and the remaining for lungs and/or skin. Rodent-attached I. ricinus (accounting for $96.3 \%$ ) and H. concinna were infected with B. microti, B. venatorum, B. capreoli/B. divergens, Babesia sp. 1 (Eurasia), and Babesia sp. 2 (Eurasia). All B. microti and B. venatorum isolates were identical to known zoonotic strains from Europe. Less than $1.0 \%$ of Babesia-positive ticks and rodents carried Candidatus N. mikurensis or A. phagocytophilum.

Conclusion: Our findings suggest that I. ricinus and rodents play important roles in the epidemiology of zoonotic Babesia spp. in south-western Slovakia. Associations with vertebrate hosts and the pathogenicity of Babesia spp. infecting $H$. concinna ticks need to be further explored.

Keywords: Piroplasmida, Babesia spp., Ixodes ricinus, Haemaphysalis concinna, Rodents, Birds, Slovakia

\section{Background}

Babesia spp. are tick-transmitted hemoprotozoans infecting a number of mammalian and some bird species, and together with Theileria spp. they are referred to as piroplasmids (order Piroplasmida) [1]. Species of Babesia vary in their virulence and can cause babesiosis in humans and animals [2]. The first case of human babesiosis in Europe was reported from Croatia in 1957 [3]. Since then, the

\footnotetext{
* Correspondence: maria.kazimirova@savba.sk

${ }^{1}$ Institute of Zoology, Slovak Academy of Sciences, Dúbravská cesta 9, 84506 Bratislava, Slovakia

Full list of author information is available at the end of the article
}

number of cases in Europe has increased [4, 5]. Three cases of human babesiosis have been reported from Slovakia since 1991 [6]. Based on classical taxonomy, piroplasmids include three groups: (i) Theileria, i.e. Theileria capreoli (Clade V as defined in [1]); (ii) Babesia (sensu stricto), i.e. Babesia canis, Babesia venatorum, Babesia odocoilei, Babesia divergens and B. capreoli (Clade VI as defined in [1]); and (iii) Babesia (sensu lato), i.e. Babesia microti (Clade I as defined in [1]) [1, 7]. Molecular phylogenetic analyses confirmed that $B$. microti is a species complex, consisting of genetically diverse isolates that fall into a number of different clades [8]. Within these clades, 
the zoonotic "Jena" type [9] and the non-zoonotic "Munich" type [10] can be discriminated between rodent isolates from Europe. Common causative agents of human babesiosis in Europe are Babesia divergens and the $B$. divergens-like species, $B$. venatorum, and $B$. microti-like species [2].

Ixodid ticks are the primary vectors of Babesia spp. Zoonotic species of Babesia are transmitted mostly by species of the genus Ixodes. Ixodes ricinus is a common tick species in Slovakia [11] and in some areas it is known to cooccur with other species, such as Ixodes trianguliceps [12], Dermacentor reticulatus [13] and Haemaphysalis concinna $[11,13]$. The immature stages of I. ricinus, $H$. concinna and Dermacentor spp. ticks feed on small and mediumsized mammals and, in addition, immature I. ricinus and $H$. concinna ticks are ectoparasites of birds $[14,15]$. In contrast, adults of these tick species parasitize medium and large-sized mammals. Large domestic and wildliving ruminants (e.g. cattle and roe deer), but also ticks, due to transovarial transmission, can serve as reservoirs for $B$. divergens and $B$. venatorum. Small mammals are reservoirs for the transtadiallytransmitted B. microti [16, 17]. Some bird species can potentially contribute to the spread of piroplasmids by carrying infected ticks, infect ticks via infectious blood, or act as hosts for transmission of pathogens between ticks through co-feeding [18].

Data on the presence of piroplasmids and their medical and veterinary importance in Slovakia are rare and limited to a few studies. Some studies focused on Babesia spp. present in I. ricinus [13, 19] and rodents [12], while others dealt with $B$. canis infections in $D$. reticulatus ticks or dogs [20,21]. Although the presence of piroplasmids in $H$. concinna was confirmed in neighbouring countries [22, 23], to our knowledge the competence of $H$. concinna to transmit Babesia parasites has not been studied in Slovakia.

Recently, the geographic area where piroplasmids have been detected in ticks and cases of babesiosis have been recognized has expanded and new species of Babesia have been found [23-25]. Therefore, local investigations are essential to assess the emergence of new parasites and the potential risk of human and animal diseases.

The main objective of this study was: (i) to investigate the presence and determine the prevalence and diversity of Babesia spp. in selected wild-living vertebrate hosts, focusing on rodents and birds, and on questing ticks and ticks feeding on rodents in two different habitat types of south-western Slovakia with sympatric occurrence of $I$. ricinus and $H$. concinna ticks; (ii) to assess ecological associations and phylogenetic relationships of the Babesia spp. found in ticks and vertebrate hosts in the study area; and (iii) to assess co-infections of Babesia-infected ticks and rodents with other microorganisms.

\section{Methods}

Study area, collection of ticks, trapping of rodents and birds, ethical approval

The two study sites are located in the Small Carpathian Mountains (south-western Slovakia) and differ in their habitat type. The first site (48.17-48.20 N, 17.07-17.10E) is characterized by significant human intervention and represents an urban/suburban habitat in Bratislava used for relaxing, cycling, dog walking, and jogging among others. The second site $(48.37-48.38 \mathrm{~N}, 17.30-17.32 \mathrm{E})$ is a natural habitat at Fúgelka represented by a non-fragmented forest, predominantly perambulated by hikers, foresters, and gamekeepers [for details, see 11]. Collection of questing ticks and trapping of rodents were performed as described previously [26]. In brief, questing ticks were collected from year 2011 to 2013 by dragging the vegetation and subsequently their species identity and life stage was determined. Rodents were livetrapped from year 2012 to 2014 by using Swedish bridge metal traps and sacrificed according to current laws of the Slovak Republic, approved by the Ministry of Environment of the Slovak Republic, Regional Environmental Office in Bratislava (licence ZPO-594/2012-SAB). Blood samples were obtained from sinus orbitalis, spleens, lungs, skin biopsy samples taken from ears (further as "skin"), and rodent-attached ticks were gathered from each rodent (at least five specimens of each tick species and life stage, respectively) for further analysis. Ornithological mist nets were used to trap wild-living birds in the urban/suburban habitat during 2012-2013. Each captured bird was identified, ringed, inspected for ectoparasites (data not shown) and blood samples were taken from the vena ulnaris cutanea before release as described in [27]. Birds were handled under the permission of the Ministry of Environment of the Slovak Republic, No. 9368/2011-2.2.

\section{DNA extraction}

Genomic DNA was isolated from individual ticks and rodent tissues by using the Macherey-Nagel NucleoSpin ${ }^{\circ}$ Tissue kit (Düren, Germany) according to the manufacturer's instructions. Quantity and quality of the isolated DNA was assessed with a spectrophotometer Nanodrop 2000c and stored at $-20{ }^{\circ} \mathrm{C}$ until further studied.

\section{PCR amplification and sequence analysis}

DNA amplification by PCR was carried out following the protocol described by [28]. Babesia genus-specific BJ1 (5'-GTC TTG TAA TTG GAA TGA TGG-3') and BN2 (5'-TAG TTT ATG GTT AGG ACT ACG-3') primers were used to amplify a $450 \mathrm{bp}$ region of the $18 \mathrm{~S}$ ribosomal RNA gene. PCR reactions were carried out in a volume of $25 \mu \mathrm{l}$ containing $5 \mu \mathrm{l}$ of DNA template and $20 \mu \mathrm{l}$ of PCR mix: $0.125 \mu \mathrm{l}$ of HotStarTaq Plus DNA Polymerase ( $5 \mathrm{U} / \mu \mathrm{l}$; Qiagen, Hilden, Germany), $0.5 \mu \mathrm{l}$ of each 
primer $(10 \mu \mathrm{M}), 0.5 \mu \mathrm{l}$ of dNTP $(10 \mathrm{mM}), 2.5 \mu \mathrm{l}$ of Coral Load PCR buffer (containing $15 \mathrm{mM} \mathrm{MgCl}$ ), $1 \mu \mathrm{l}$ of $\mathrm{MgCl}_{2}(25 \mathrm{mM})$ and $14.875 \mu \mathrm{l}$ of nuclease free water. Negative as well as positive controls were included in each run. Amplification was performed in a BioRad t 100 thermal cycler (USA). The thermal cycle reaction consisted of an initial denaturation step $\left(5 \mathrm{~min}\right.$ at $\left.95{ }^{\circ} \mathrm{C}\right)$, followed by 35 cycles of denaturation $\left(1 \mathrm{~min}\right.$ at $\left.94{ }^{\circ} \mathrm{C}\right)$, annealing $\left(1 \mathrm{~min}\right.$ at $\left.55{ }^{\circ} \mathrm{C}\right)$, and elongation $\left(2 \mathrm{~min}\right.$ at $\left.72{ }^{\circ} \mathrm{C}\right)$. A final extended amplification step of $5 \mathrm{~min}$ at $72{ }^{\circ} \mathrm{C}$ was carried out. PCR products were separated by electrophoresis in a $1.5 \%$ agarose gel and treated with GoodView $^{\text {тu }}$ Nucleic Acid stain (SBS Genetech, China) to be visualized by UV transillumination.

PCR positive samples were purified and analysed by sequencing with forward and reverse primers used for PCR amplification by Macrogen (Amsterdam, the Netherlands). Sequences were deposited in the GenBank database under accession numbers KU362887-KU362905 and KU550676 - KU550699.

\section{Phylogenetic analysis}

Determined 18S rRNA gene nucleotide sequences were used as query in a BLASTn search in order to identify and download most closely related 18S rRNA gene sequences of well-defined piroplasmid species from GenBank. In addition, 18S rRNA gene sequences of representative piroplasmid species were downloaded in order to allow species delineation in the phylogenetic analysis. A multiple alignment of the hypervariable region of $9518 \mathrm{~S}$ rRNA gene sequences comprising selected and analysed sequences including the 18S rRNA gene of Cardiosporidium cionae was done using MUSCLE [29]. Positions containing gaps and missing data were eliminated from the 514 nucleotide-alignment to finally result in 385 positions in the final dataset. After estimation of shape parameter, the $\mathrm{K} 2+\mathrm{G}+\mathrm{I}$ parameter model was applied to generate a maximum likelihood tree [30]. Phylogenetic analysis was carried out using the MEGA6 software [31].

\section{Statistical analyses}

Differences in the prevalence of infection with Babesia spp. in questing ticks, ticks attached to rodents, and in rodents were analysed between habitats, years, and rodent species and genders applying Fisher's exact test, supplemented with Mantel-Haenszel common odds ratio estimate and its $95 \%$ confidence interval in cases when two prevalences were compared. Rodents positive for spleen, blood and/or lungs were considered Babesia-positive. The $95 \%$ confidence intervals of the prevalences in questing ticks, rodent-attached ticks and rodents were computed using a bootstrap technique. Logistic regression was used to estimate the effect of habitat type and year on the probability of tick infection and the effect of habitat type, rodent species and gender on the probability of rodent infection. Backward stepwise method was used to find the set of variables significantly affecting the probability of tick and rodent infection. Tests for the significance of the effects in the model were performed via the Wald statistic. Results on the presence of $A$. phagocytophilum and Candidatus N. mikurensis (CNM) in the same questing ticks, and rodents available from previous studies [26,32], were used to calculate the probability of co-infections with Babesia spp. and analyse the dependence of the microorganisms on the habitat type using Fisher's exact test. Differences were considered significant at $P<0.05$ in all tests. Statistical analyses were performed with IBM SPSS Statistics, version 22 [33] and Statistica software, version 12 [34].

\section{Results}

Babesia spp. in questing ticks

A total of 5057 I. ricinus (3158 nymphs and 1899 adults) and $91 \mathrm{H}$. concinna (59 nymphs and 32 adults) were examined, resulting in an overall Babesia spp. infection prevalence of $1.5 \%$ (Table 1) and $6.6 \%$ (Additional file 1 : Table S1), respectively. The overall prevalence of Babesiainfected $I$. ricinus ticks was significantly higher in Fúgelka than in Bratislava $(2.0 \%$ vs $1.2 \% ; P=0.022$; $\mathrm{OR}=1.7$; CI: 1.1-2.7) (Table 1). Differences in prevalence of infection between sites were also significant for tick females $(P=0.016$; OR $=10.4 ; C I: 1.2-89.5)$, but not for males $(P=0.560$; $\mathrm{OR}=0.6$; CI: $0.2-2.1)$ and nymphs $(P=0.088$; $\mathrm{OR}=1.6$; CI: $0.9-2.7$ ) (Table 1). No significant differences were found between infection prevalence in I. ricinus nymphs and adults (Bratislava: $P=0.218$; $\mathrm{OR}=1.7$; $\mathrm{CI}$ : $0.8-3.4$; Fúgelka: $P=0.134$; $\mathrm{OR}=1.8$; $\mathrm{CI}$ : $0.8-3.9)$. By comparing the prevalence of infection with Babesia spp. in I. ricinus between the three years (2011-2013), significant difference was revealed only for nymphs and for total prevalence in Bratislava (Table 1).

Overall prevalence of Babesia spp.-infected H. concinna ticks was higher in Bratislava compared to Fúgelka, but the difference was not significant $(8.9 \%$ vs $2.9 \%$; $P=0.400$; $\mathrm{OR}=3.3$; CI: 0.4-29.8) (for details see Additional file 1: Table S1).

By comparing the two tick species, overall prevalence of infection with Babesia spp. was found to be significantly higher in $H$. concinna than in I. ricinus from Bratislava (8.9 \% vs $1.2 \% ; P=0.001$; OR $=8.2$; CI: $3.1-21.9$ ). In contrast, no significant difference between the prevalence of infected $H$. concinna and $I$. ricinus was found at Fúgelka ( $2.9 \%$ vs $2.0 \%$; $P=0.511$; OR $=1.4 ;$ CI: $0.2-10.8)$.

The occurrence of various species of Babesia in questing $I$. ricinus differed between habitats as well as between nymphs and adults (Fig. 1). The dependence of the occurrence of Babesia spp. on the habitat was significant $(P=0.002)$. Ticks infected with $B$. microti prevailed in the natural habitat (Bratislava: $27.3 \%$; Fúgelka: 
Table 1 Prevalence of Babesia spp. in questing Ixodes ricinus per site in 2011-2013

\begin{tabular}{|c|c|c|c|c|c|c|c|c|c|c|}
\hline \multirow[b]{2}{*}{ Site } & & \multicolumn{2}{|l|}{2011} & \multicolumn{2}{|l|}{2012} & \multicolumn{2}{|l|}{2013} & \multirow{2}{*}{$\begin{array}{l}\text { Fisher's } \\
\text { exact test } P\end{array}$} & \multicolumn{2}{|l|}{ Total } \\
\hline & & $\%$ (pos/ex) & $95 \% \mathrm{Cl}$ & $\%$ (pos/ex) & $95 \% \mathrm{Cl}$ & $\%$ (pos/ex) & $95 \% \mathrm{Cl}$ & & $\%$ (pos/ex) & $95 \% \mathrm{Cl}$ \\
\hline \multirow[t]{5}{*}{ Bratislava } & Nymphs & $0.9(8 / 883)$ & $0.3-1.6$ & $4.1(8 / 195)$ & $1.5-7.2$ & $1.3(6 / 455)$ & $0.4-2.6$ & 0.007 & $1.4(22 / 1533)$ & $0.8-2.0$ \\
\hline & Females & $0.3(1 / 367)$ & $0-0.8$ & $0(0 / 61)$ & - & $0(0 / 156)$ & - & 1.000 & $0.2(1 / 584)$ & $0-0.5$ \\
\hline & Males & $0.9(4 / 437)$ & $0.2-1.8$ & $1.5(1 / 68)$ & $0-4.4$ & $2.8(5 / 177)$ & $0.6-5.6$ & 0.189 & $1.5(10 / 682)$ & $0.7-2.5$ \\
\hline & Adults total & $0.6(5 / 804)$ & $0.1-1.2$ & $0.8(1 / 129)$ & $0-2.3$ & $1.5(5 / 333)$ & $0.3-3.0$ & 0.316 & $0.9(11 / 1266)$ & $0.4-1.3$ \\
\hline & Total & $0.8(13 / 1687)$ & $0.4-1.2$ & $2.8(9 / 324)$ & $0.9-4.6$ & $1.4(11 / 788)$ & $0.6-2.3$ & 0.010 & $1.2(33 / 2799)$ & $0.8-1.6$ \\
\hline \multirow[t]{5}{*}{ Fúgelka } & Nymphs & $2.2(23 / 1067)$ & $1.3-3.1$ & $3.4(10 / 295)$ & $1.4-5.4$ & $1.5(4 / 263)$ & $0.4-3.0$ & 0.319 & $2.3(37 / 1625)$ & $1.6-3.0$ \\
\hline & Females & $3.3(5 / 150)$ & $0.7-6.7$ & $0(0 / 59)$ & - & $0(0 / 76)$ & - & 0.128 & $1.8(5 / 285)$ & $0.4-3.5$ \\
\hline & Males & $0.6(1 / 164)$ & $0-2.4$ & $0(0 / 82)$ & - & $2.0(2 / 102)$ & $0-4.9$ & 0.450 & $0.9(3 / 348)$ & $0-2.0$ \\
\hline & Adults total & $1.9(6 / 314)$ & $0.6-3.5$ & $0(0 / 141)$ & - & $1.1(2 / 178)$ & $0-2.8$ & 0.294 & $1.3(8 / 633)$ & $0.5-2.2$ \\
\hline & Total & $2.1(29 / 1381)$ & $1.4-2.9$ & $2.3(10 / 436)$ & $0.9-3.7$ & $1.4(6 / 441)$ & $0.5-2.5$ & 0.554 & $2.0(45 / 2258)$ & $1.4-2.6$ \\
\hline Total & & $1.4(42 / 3068)$ & $0.9-1.8$ & $2.5(19 / 760)$ & $1.4-3.7$ & $1.4(17 / 1229)$ & $0.7-2.0$ & 0.086 & $1.5(78 / 5057)$ & $1.2-1.9$ \\
\hline
\end{tabular}

(pos/ex), number of positive/number of examined; $95 \% \mathrm{Cl}$, confidence interval

$72.7 \%)$, whereas the proportion of ticks infected with $B$. venatorum was similar between both habitats (Bratislava: 53.8 \%; Fúgelka: $46.2 \%$ ) (see Additional file 1: Table S2). Babesia canis (from four nymphs and one male) and Babesia odocoilei (from one nymph) were exclusively found in I. ricinus from Bratislava. Babesia capreoli/B. divergens was found in adult $I$. ricinus ticks from Bratislava and in one $I$. ricinus nymph from Fúgelka (Fig. 1). Furthermore, Babesia sp. 1 (Eurasia) (from four nymphs and one female from Bratislava) and Babesia sp. 2 (Eurasia) (from one male from Fúgelka) were found to infect questing $H$. concinna ticks.

The occurrence of Babesia spp. also differed significantly between years $(P=0.004)$. The proportion of B. microti-infected ticks was the higest in 2011 (50.0\%) and the lowest in 2013 (11.4\%). The proportion of B. venatorum-infected ticks was also the higest in 2011 $(57.7 \%)$ but it was the lowest in 2012 (7.7 \%) (see
Additional file 1: Table S3). There was also a significant difference in the proportion of tick developmental stages infected with $B$. microti and $B$. venatorum $(P=0.012)$. This was most obvious for B. microti, which was more prevalent in nymphs than in adults (86.4 \% vs $13.6 \%$ ). In the other Babesia spp. the trend was not so strong (see Additional file 1: Table S4).

In addition to Babesia spp., Theileria sp. DNA was detected in two $H$. concinna nymphs from Bratislava.

The analysis of simultaneous effects of habitat and year on the probability of the overall infection of $I$. ricinus with Babesia spp. by logistic regression resulted in a significant effect of habitat (Bratislava: parameter estimate $\mathrm{B}=-0.533, \exp (\mathrm{B})=0.587, P=0.021)$. The variable removed by backward method was year. Considering only infections with $B$. microti, logistic regression confirmed the significant effect of habitat, with about three

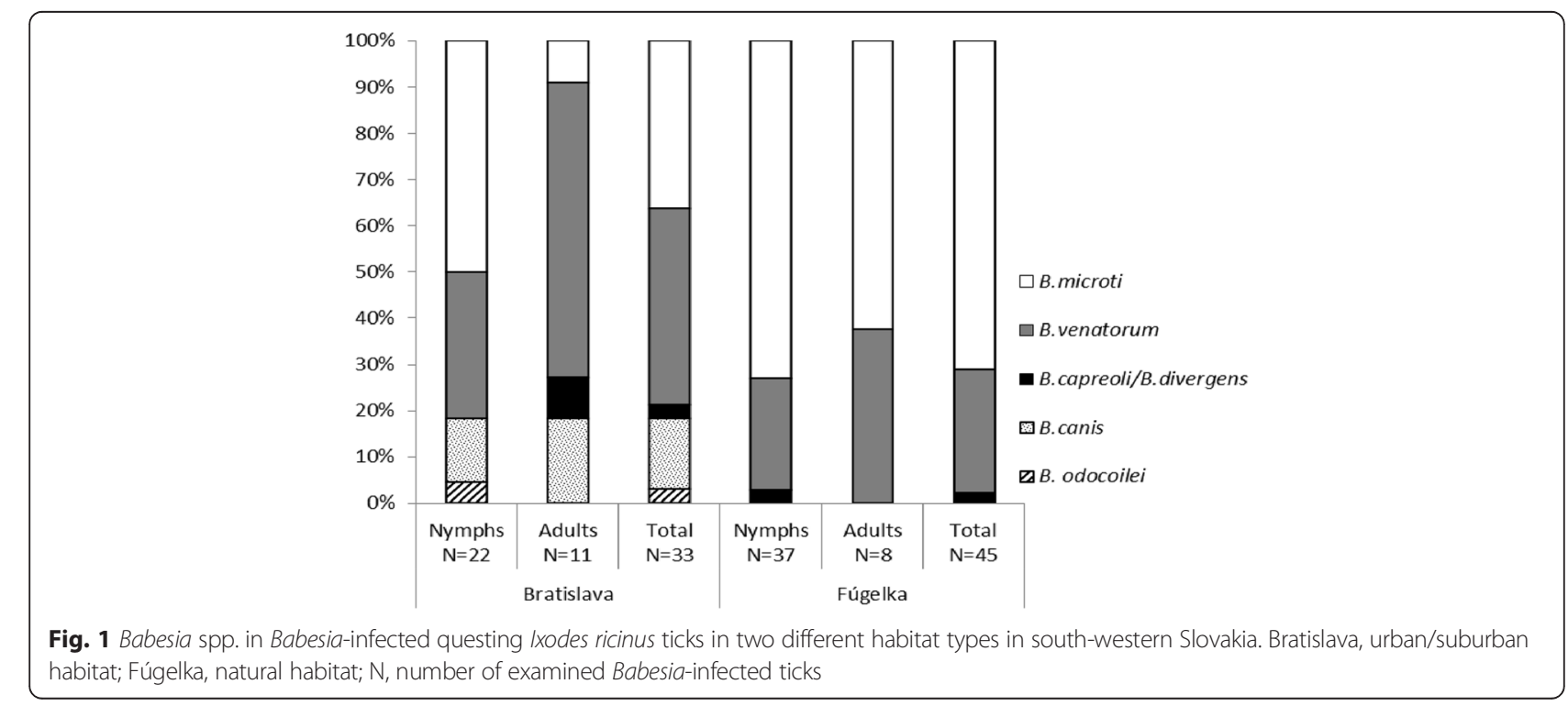


times lower probability of infection of ticks in the urban habitat (Bratislava: parameter estimate $\mathrm{B}=-1.064$, $\exp (B)=0.345, P=0.002$ ). In contrast, none of the variables were found to predict the infection of I. ricinus with B. venatorum.

\section{Babesia microti in rodents}

Altogether, 606 rodents of six species (356 Apodemus flavicollis, 227 Myodes glareolus, 19 Microtus arvalis, 2 Apodemus sylvaticus, 1 Microtus subterraneus, 1 Micromys minutus) were screened for the presence of piroplasmids. Babesia microti was detected in spleen and/or blood and/or lungs of $1.3 \%$ and $4.2 \%$ of the examined rodents from Bratislava and Fúgelka, respectively (Table 2), with statistically significant difference between the two sites $(P=0.046$; OR $=3.3$; CI: $1.1-10.2)$. DNA of the parasite was also detected in lungs and skin biopsies from ears of rodents with positive spleens: in 3 lungs and 2 skin samples from rodents in Bratislava, and in 8 lungs and 7 skin samples from rodents in Fúgelka. Out of the 17 positive rodents, $47.1 \%$ belonged to A. flavicollis, $47.1 \%$ to M. arvalis and $5.8 \%$ to M. glareolus. By comparing total $B$. microti infection prevalence between mice (the group comprises A. flavicollis, A. sylvaticus and M. minutus), M. glareolus, and Microtus spp. (the group comprises $M$. arvalis and $M$. subterraneus), a significant difference was determined $(P<0.001)$, with higher prevalence in Microtus spp. Overall, the parasite was found in $2.2 \%$ (CI: 0.8-3.9\%) of mice, in $0.4 \%$ (CI: $0.0-1.3 \%$ ) of $M$. glareolus and in $40.0 \%$ (CI: 20.0-60.0 \%) of Microtus spp. In addition, out of the rodents from Fúgelka (not included in the statistical analyses) that had negative spleen, blood and lungs, two M. glareolus females had positive skin.

The prevalence of infection with $B$. microti was significantly higher in male rodents $(4.4 \%$ vs $1.1 \% ; P=0.014$; $\mathrm{OR}=4.3$; CI: $1.2-15.1$ ), but no significant differences were found between genders of individual species except for Microtus spp. in Fúgelka (Table 2).
Significant difference in the overall prevalence of infection with $B$. microti was determined between years: 3.7 and $25.0 \%$ of rodents were found to be positive in 2012 and 2013, respectively, but no rodent was found to be infected in $2014(P=0.004)$ (Table 3$)$. Considering habitat, the difference between years was statistically significant in Fúgelka, but not in Bratislava (Table 3).

Simultaneous effects of habitat, rodent species, and gender on the probability of infection with $B$. microti, analysed by logistic regression, resulted in a significant effect of species (mice: parameter estimate $\mathrm{B}=-4.142$, $\exp (\mathrm{B})=0.016, P<0.001 ;$ Myodes: parameter estimate $\mathrm{B}=-5.755, \exp (\mathrm{B})=0.003, P<0.001)$ and gender (males: parameter estimate $\mathrm{B}=2.345$, $\exp (\mathrm{B})=10.431, P=0.004)$. The variable removed by backward method was habitat (see Additional file 1: Table S5). The probability of infection was the highest for Microtus spp., and the risk of infection of rodent males was ten times higher than that of females.

\section{Babesia spp. in rodent-attached ticks}

In total, 2003 engorged ixodid ticks were collected from rodents: 1089 and $840 \mathrm{I}$. ricinus, 30 and $39 \mathrm{H}$. concinna from Bratislava and Fúgelka, respectively, 4 I. trianguliceps from Bratislava and $1 \mathrm{D}$. reticulatus from Fúgelka. Altogether, 1140 (695 and 445 from Bratislava and Fúgelka, respectively) rodent-attached ticks were screened: 1075 I. ricinus (1044 larvae, 28 nymphs, 3 females), 60 H. concinna (56 larvae, 4 females), 4 I. trianguliceps (2 larvae, 2 nymphs), and $1 D$. reticulatus larva. Piroplasmids were detected in $I$. ricinus (immature stages and 1 female) and $H$. concinna (larvae and females), but not in I. trianguliceps and $D$. reticulatus (Table 4 ).

Thirty-eight out of 1140 (3.3\%; CI: 2.3-4.5\%) rodentattached ticks were positive for Babesia spp., whereby 30 of them were collected from $B$. microti-positive rodents and the remaining from Babesia-negative specimens (Table 4). Individual B. microti-positive rodents carried 1 to 14 Babesia-positive ticks, whereby 9 of 300 (3.0\%; CI:

Table 2 Prevalence of Babesia microti in rodents per species, gender and site

\begin{tabular}{|c|c|c|c|c|c|c|c|c|}
\hline \multirow[b]{2}{*}{ Site } & \multirow[b]{2}{*}{ Species } & \multicolumn{2}{|l|}{ Males } & \multicolumn{2}{|l|}{ Females } & \multirow{2}{*}{$\begin{array}{l}\text { Fisher's } \\
\text { exact test } P\end{array}$} & \multicolumn{2}{|l|}{ Total } \\
\hline & & $\%$ (pos/ex) & $95 \% \mathrm{Cl}$ & $\%$ (pos/ex) & $\overline{95 \% \mathrm{Cl}}$ & & $\%$ (pos/ex) & $95 \% \mathrm{Cl}$ \\
\hline \multirow[t]{3}{*}{ Bratislava } & Mice $^{a}$ & $4.1(4 / 97)$ & $1.0-8.2$ & $0(0 / 84)$ & - & 0.125 & $2.2(4 / 181)$ & $0.6-5.0$ \\
\hline & M. glareolus & $0(0 / 65)$ & - & $0(0 / 54)$ & - & - & $0(0 / 119)$ & - \\
\hline & Total & $2.5(4 / 162)$ & $0.6-4.9$ & $0(0 / 138)$ & - & 0.127 & $1.3(4 / 300)$ & $0.3-2.7$ \\
\hline \multirow[t]{4}{*}{ Fúgelka } & Mice $^{a}$ & $3.1(3 / 98)$ & $0-7.1$ & $1.3(1 / 80)$ & $0-3.8$ & 0.629 & $2.2(4 / 178)$ & $0.6-4.5$ \\
\hline & M. glareolus & $1.9(1 / 53)$ & $0-5.7$ & $0(0 / 55)$ & - & 0.491 & $0.9(1 / 108)$ & $0-3.7$ \\
\hline & Microtus spp.b & $75.0(6 / 8)$ & $37.5-100.0$ & $16.7(2 / 12)$ & $0-41.7$ & 0.019 & $40.0(8 / 20)$ & $20.0-60.0$ \\
\hline & Total & $6.3(10 / 159)$ & $2.5-10.1$ & $2.0(3 / 147)$ & $0-4.8$ & 0.089 & $4.2(13 / 306)$ & $2.0-6.5$ \\
\hline Total & & $4.4(14 / 321)$ & $2.2-6.5$ & $1.1(3 / 285)$ & $0-2.5$ & 0.014 & $2.8(17 / 606)$ & $1.7-4.3$ \\
\hline
\end{tabular}

(pos/ex), number of positive/number of examined; $95 \% \mathrm{Cl}$, confidence interval; ${ }^{2}$ Mice comprise Apodemus flavicollis, Apodemus sylvaticus (1 female from Bratislava, 1 male from Fúgelka) and one Micromys minutus male from Fúgelka; ${ }^{\mathrm{b}}$ Microtus spp. comprises of Microtus arvalis and one Microtus subterraneus female 
Table 3 Prevalence of Babesia microti in rodents per site in 2012-2014

\begin{tabular}{|c|c|c|c|c|c|c|c|}
\hline \multirow[b]{2}{*}{ Site } & \multicolumn{2}{|l|}{2012} & \multicolumn{2}{|l|}{2013} & \multicolumn{2}{|l|}{2014} & \multirow[t]{2}{*}{ Fisher's exact test $P^{a}$} \\
\hline & $\%$ (pos/ex) & $95 \% \mathrm{Cl}$ & $\%$ (pos/ex) & $95 \% \mathrm{Cl}$ & $\%$ (pos/ex) & $95 \% \mathrm{Cl}$ & \\
\hline Bratislava & $1.1(2 / 185)$ & $0-2.7$ & $33.3(2 / 6)$ & $0-66.7$ & $0(0 / 109)$ & - & 0.532 \\
\hline Fúgelka & $5.9(13 / 222)$ & $2.7-9.5$ & $0(0 / 2)$ & - & $0(0 / 82)$ & - & 0.023 \\
\hline Total & $3.7(15 / 407)$ & $1.7-5.7$ & $25.0(2 / 8)$ & $0-62.5$ & $0(0 / 191)$ & - & 0.004 \\
\hline
\end{tabular}

(pos/ex), number of positive/number of examined; $95 \% \mathrm{Cl}$, confidence interval; ${ }^{2}$ only years 2012 and 2014 were compared

$1.3-5.3 \%)$ and 6 of 306 (2.0\%; CI: 0.7-3.6 \%) rodents carried Babesia-positive ticks in Bratislava and Fúgelka, respectively. The prevalence of infection in rodentattached ticks did not differ significantly between the two sites $(P=0.445 ; \mathrm{OR}=1.5$; CI: $0.5-4.4)$. In addition to the most prevalent $B$. microti, a few rodent-attached $I$. ricinus ticks carried $B$. venatorum and $B$. capreoli/B. divergens. In rodent-attached $H$. concinna, B. microti, Babesia sp. 1 (Eurasia), Babesia sp. 2 (Eurasia) and Theileria sp. were detected (Table 4).

\section{Co-infections in ticks and rodents}

With regard to co-infections and prevalence patterns, we analysed results for Babesia spp. and data from previous studies on prevalences of A. phagocytophilum and CNM in ticks and rodents [26, 32]. Out of the 3874 questing I. ricinus screened for the presence of the three microorganisms, co-infection of Babesia spp. and A. phagocytophilum was detected in two ticks $(0.05 \%$; one male infected with $B$. venatorum and one nymph infected with $B$. canis from Bratislava). Co-infection of Babesia spp. and CNM was

Table 4 Dissemination of Babesia microti in infected rodents and infestation of rodents with Babesia (Theileria)-positive ticks

\begin{tabular}{|c|c|c|c|c|c|c|c|c|c|c|}
\hline \multirow[b]{2}{*}{ Site } & \multicolumn{6}{|l|}{ Rodents } & \multicolumn{4}{|c|}{ Engorged I. ricinus, $\quad$ H. concinna, $\quad$ I. trianguliceps } \\
\hline & Species & Gender & Spleen & Blood & Lungs & Skin & $\begin{array}{l}\text { Larvae } \\
\text { pos/ex/total }\end{array}$ & $\begin{array}{l}\text { Nymphs } \\
\text { pos/ex/total }\end{array}$ & $\begin{array}{l}\text { Adults } \\
\text { pos/ex/total }\end{array}$ & Piroplasmid species \\
\hline \multirow[t]{10}{*}{ Bratislava } & A. flavicollis & $\sigma^{\pi}$ & & & & & $0 / 4 / 4, * 1 / 1 / 1$ & 0 & 0 & Babesia sp. 2 (Eurasia) \\
\hline & A. flavicollis & $\sigma^{\lambda}$ & & & & & $0 / 2 / 2$ & $0 / 1 / 1$ & 0 & \\
\hline & A. flavicollis & 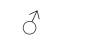 & & & & & $4 / 7 / 7$ & 0 & 0 & Babesia sp. \\
\hline & A. flavicollis & 우 & & & & & $0 / 9 / 9$ & 0 & $1 / 1 / 1$ & Babesia sp. \\
\hline & A. flavicollis & $\sigma^{\lambda}$ & & & & & $0 / 5 / 64$ & $1 / 10 / 16$ & 0 & B. venatorum \\
\hline & A. flavicollis & $\sigma^{\pi}$ & & & & & $5 / 5 / 35$ & $8 / 10 / 16$ & $*_{1 / 1 / 1}$ & B. microti \\
\hline & A. flavicollis & $\sigma^{2}$ & & & & & $1 / 2 / 2$ & 0 & 0 & B. capreoli/B. divergens \\
\hline & A. flavicollis & 우 & & & & & $0 / 1 / 1, * 1 / 1 / 1$ & 0 & 0 & Babesia sp. 1 (Eurasia) \\
\hline & M. glareolus & $\hat{\sigma}$ & & & & & $1 / 1 / 1$ & 0 & 0 & B. venatorum \\
\hline & M. glareolus & 우 & & & & & $0 / 5 / 9, * 2 / 2 / 2$ & $* * 0 / 1 / 1$ & 0 & Babesia sp. 1 (Eurasia) \\
\hline \multirow[t]{15}{*}{ Fúgelka } & A. flavicollis & $\hat{\sigma}$ & & & & & $0 / 1 / 1, * 1 / 1 / 1$ & 0 & 0 & B. microti \\
\hline & A. flavicollis & $\hat{\sigma}$ & & & & & $0 / 2 / 4, * 1 / 1 / 1$ & 0 & 0 & Babesia sp. 1 (Eurasia) \\
\hline & A. flavicollis & $\sigma^{\pi}$ & & & & & 0 & 0 & 0 & \\
\hline & A. flavicollis & $\sigma^{\top}$ & & & NA & & $0 / 2 / 2$ & 0 & 0 & \\
\hline & A. flavicollis & q & & & & & $4 / 7 / 7, * 0 / 1 / 1$ & 0 & 0 & B. microti \\
\hline & A. flavicollis & 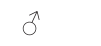 & & & & & 0 & 0 & 0 & \\
\hline & M. arvalis & $\sigma^{2}$ & & & & & $2 / 2 / 2$ & $1 / 1 / 1$ & 0 & B. microti \\
\hline & M. arvalis & 우 & & & & & 0 & 0 & 0 & \\
\hline & M. arvalis & $\widehat{0}$ & & & NA & & $0 / 7 / 7, * 0 / 7 / 7$ & 0 & 0 & \\
\hline & M. arvalis & $\widehat{0}$ & & & & & 0 & 0 & $*_{1 / 1 / 1}$ & B. microti \\
\hline & M. arvalis & 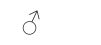 & & & & & $*_{1 / 1}$ & 0 & $1 / 1 / 1$ & B. microti \\
\hline & M. arvalis & $\sigma^{\lambda}$ & & & NA & & $0 / 1 / 1$ & 0 & $* 1 / 2 / 2$ & Theileria sp. \\
\hline & M. arvalis & 우 & & NA & & & 0 & 0 & 0 & \\
\hline & M. arvalis & 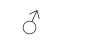 & & & & & 0 & 0 & 0 & \\
\hline & M. glareolus & 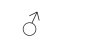 & & & NA & & 0 & 0 & 0 & \\
\hline
\end{tabular}

Grey, Babesia-positive; white, Babesia-negative; pos/ex/total, number of positive (positive by amplification of the 18S rRNA gene fragment/number of examined ticks/number of total ticks infesting a rodent); NA, not available. The table displays all $B$. microti-positive rodents (infested and uninfested with ticks) and out of the Babesia-negative those specimens which were infested with Babesia (Theileria)-positive ticks. ${ }^{*} H$. concinna, * I. trianguliceps 
found in three ticks $(0.08 \%$; nymphs from Fúgelka, two infected with $B$. microti and one infected with $B$. venatorum). Triple infections were not detected. Comparison of the proportions of ticks infected with the microorganisms revealed significant differences between the two habitats $(P<0.001)$. Ticks infected with Babesia spp. (62.3 \%) and CNM $(65.5 \%)$ prevailed in the natural habitat, and ticks infected with A. phagocytophilum (74.7 \%) prevailed in the urban/ suburban habitat (see Additional file 1: Table S6).

Altogether, five out of the 606 examined rodents $(0.83 \%$; one A. flavicollis male from Bratislava, one A. flavicollis female, two $M$. arvalis females and one $M$. arvalis male from Fúgelka) were co-infected with $B$. microti and CNM. The proportions of rodents infected with the two microorganisms did not differ significantly between the two habitats $(P=1.000)$. Rodents infected with $B$. microti (75.0 \%; 9 out of 12) and CNM (75.0\%; 27 out of 36) prevailed in the natural habitat. No co-infection of $B$. microti and A. phagocytophilum was observed.

Considering rodent-attached ticks, only co-infection of B. microti and A. phagocytophilum was detected in three I. ricinus nymphs feeding on a $B$. microti-positive $A$. flavicollis male from Bratislava. The remaining infected engorged ticks carried only one microorganism.

\section{Babesia spp. in birds}

In total, 58 blood samples from birds representing 11 species were screened for Babesia spp. (Appendix 1). None of the birds was found to be infected.

\section{Phylogenetic analysis}

All piroplasmid-positive PCR products from questing ticks, ticks attached to rodents, and rodents originating from both study sites were sequenced and are listed in Additional file 1: Table S7. The phylogenetic analysis shows that the majority of isolates segregate with a highly significant bootstrap into clades of Theileria sp., B. microti, B. venatorum, B. canis, B. odocoilei, and a $B$. capreoli/B. divergens clade, respectively. However, some isolates segregate into two novel clades strongly suggesting that they represent previously unrecognized species designated in this study as Babesia sp. 1 (Eurasia) and Babesia sp. 2 (Eurasia), respectively (Fig. 2). In the phylogenetic analysis, all identified $B$. microti isolate sequences clustered with strong support into a single clade with the Jena/ Germany genotype (Fig. 2). Sequences of 17 isolates (KU362887-KU362896 and KU550676-KU550682; from questing and rodent-attached I. ricinus, rodent-attached $H$. concinna and from rodents) corresponding to 114 analysed $18 \mathrm{~S}$ rRNA gene sequences show a $100 \%$ sequence identity with the pathogenic B. microti Jena/Germany genotype (EF413181). Other isolates displaying a $100 \%$ sequence identity not included in the tree analysis are a $B$. microti isolate from a rodent (KJ649297) and from a questing I. ricinus from Slovakia (KJ649287).

18S rRNA gene sequences of eight isolates (KU362897 -KU362900 and KU550683-KU550686; from questing and rodent-attached I. ricinus) corresponding to 28 analysed nucleotid sequences segregated with a significant bootstrap into a single clade with the $B$. venatorum genotype (FJ215873) known to cause zoonotic babesiosis in Europe. Other deposited sequences found to be $100 \%$ identical to those of this study were a B. venatorum isolate from I. ricinus from Slovakia (KJ152840) and the Czech Republic (KJ465867), but also to a B. venatorum isolate identified in Ixodes persulcatus from Mongolia (KR493908).

$18 \mathrm{~S}$ rRNA gene sequences from isolates from five questing I. ricinus (KU362904 and KU362905) segregated with highly significant support into a clade with $B$. canis isolate AY072926 identified in a dog in Croatia. Isolate sequences identified in the GenBank database that were found to be $100 \%$ identical represent B. canis from a naturally infected domestic dog from Poland (KT844907) and an isolate identified from $D$. reticulatus from Russia (AY649326).

18S rRNA gene sequences isolated from questing I. ricinus (KU362901 and KU362902) and a sequence from a rodent-attached $I$. ricinus (KU362903) clustered in a strongly supported clade with sequences of B. capreoli and $B$. divergens. Identified sequences were also found to be $100 \%$ identical with sequences deposited in the GenBank database from B. capreoli from I. ricinus from the Czech Republic (KJ465869) and with a strain isolated from roe deer from Germany (JX627353), and $99 \%$ identical with B. divergens isolated from a roe deer from Slovenia (AY572456).

Four isolates from questing and rodent-attached $H$. concinna were placed into a strongly supported single clade with isolate Babesia sp. Kh-Hc232 from H. concinna (KJ486560) and Babesia sp. Irk-Ip525 from I. persulcatus (KJ486566). This clade represents a novel species of Babesia here designated as Babesia sp. 1 (Eurasia). The 18S rRNA gene sequence of the isolate KU550694 differs from isolate sequences KU550690-KU550693 by a single base pair.

Sequences isolated from questing and rodent-attached H. concinna ticks (KU550688 and KU550689) appeared in a strongly supported clade with the sequence of Babesia sp. Kh-Hc222 strain from H. concinna identified in Russia (KJ486568). The sequences in this clade have been designated as Babesia sp. 2 (Eurasia) as they most probably represent an additional novel species.

Other 18S rRNA gene sequences isolated in this work from I. ricinus (KU550687) clustered in a strongly supported clade with B. odocoilei isolates U16369, KC460321, AY294206, and AY144689 that are 99 \% identical with the former. However, the sequence KU550687 is also placed with strong support as sister to this clade and may represent a geographical variant of this species. Other 


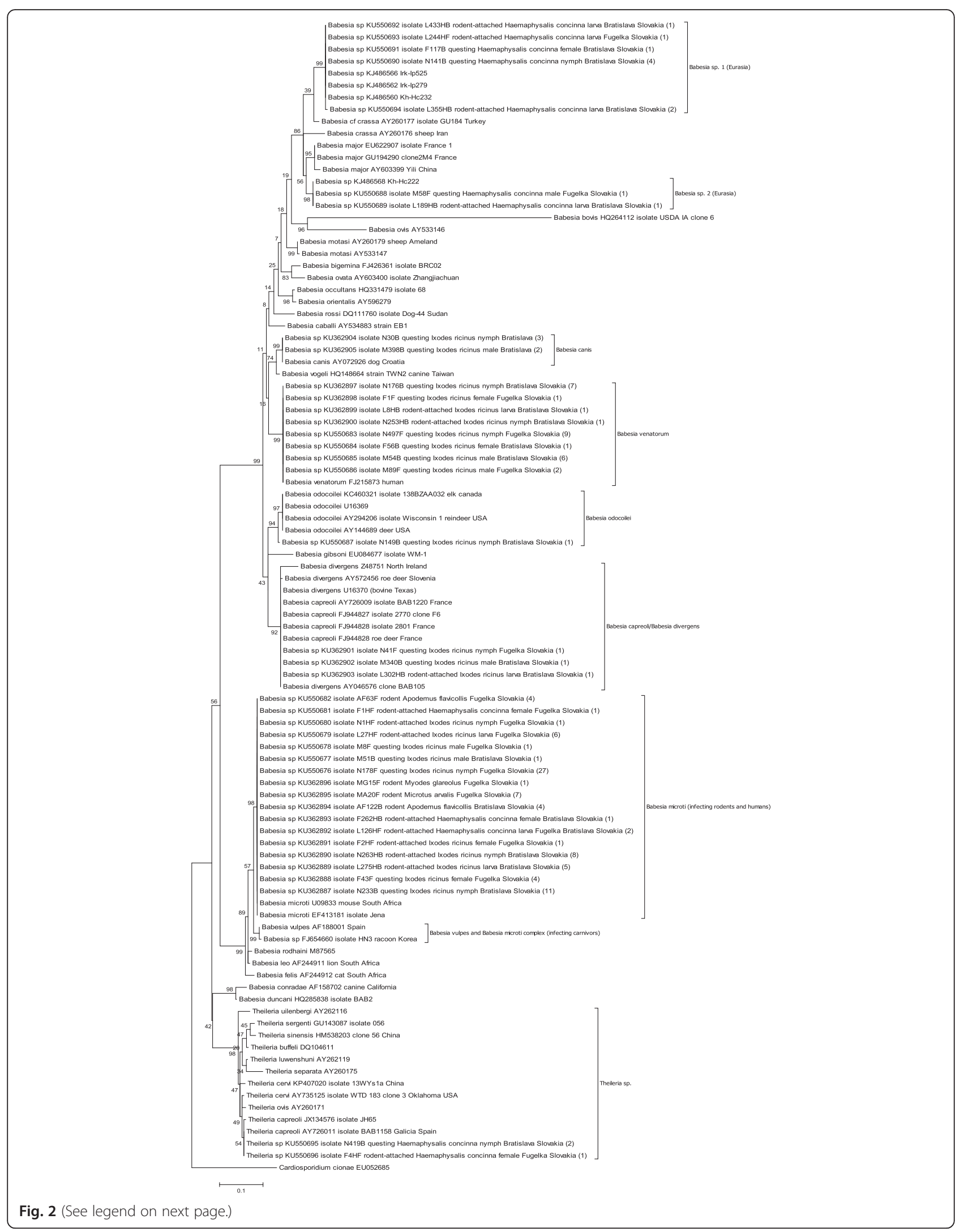


(See figure on previous page.)

Fig. 2 Phylogenetic tree of hypervariable 18S rRNA gene sequences of Babesia and Theileria parasites using maximum likelihood. The sequence of each isolate is labelled with its gene accession number, isolate designation, host (questing tick, rodent-attached tick, and rodent), and geographic origin. The bootstrap values based on 1,000 replicates are displayed next to the branches. The tree is rooted using Cardiosporidium cionae as outgroup [1]. Wherever applicable, the number of identical sequences of a given isolate type is given. All clades marked by brackets display a highly significant bootstrap value $(\geq 85)$. The evolutionary distance is shown in the units of the number of base substitutions per site

sequences identified in GenBank that are $99 \%$ identical with KU550687 are, e.g. the Norwegian strain Babesia sp. OO-2012 (JX083978) from I. ricinus, the Austrian strain Babesia cf. odocoilei (JN543180) from red deer, and the German strain B. odocoilei (JX679176) from I. canisuga.

$18 \mathrm{~S}$ rRNA gene sequences isolated from questing $H$. concinna (KU550695 and KU550696) belong to the genus Theileria as evidenced by their placement into this strongly supported clade. Placement of species of Theileria within this clade displays non-significant bootstraps and thus the species identity of KU550695 and KU550696 cannot be finally verified. However, these are most closely related to Theileria capreoli isolates JX134576 and AY26011 displaying a 99 \% identity. Isolate sequence KU550695 is $100 \%$ identical to GenBank deposited sequences of a Theileria sp. isolate from fox from Croatia (HM212629) and to a strain from roe deer from Spain (DQ866842) while sequence (KU550696) is $100 \%$ identical with a Theileria sp. isolate from red deer from Poland (DQ520836). The 18S rRNA gene sequence of isolate KU550695 differs from isolate sequence KU550696 by a single base pair.

\section{Other Apicomplexa detected in ticks and rodents}

Isolates from four questing I. ricinus showed identity with Hepatozoon canis DNA. Hepatozoon spp. DNA was also identified in $26 \mathrm{M}$. glareolus and one A. flavicollis (manuscript in preparation).

18S rRNA gene sequences from six isolates from rodent skin biopsies showed identity with corresponding sequences of Sarcocystis spp. Four identical sequences from $M$. arvalis (KU550697) revealed a $96 \%$ identity to the $18 \mathrm{~S}$ rRNA gene sequence of Sarcocystis sp. from the large oriental voles (Eothenomys miletus) from China (KF309698 and KF309699). One sequence from M. glareolus (KU550699) showed a $97 \%$ identity to the same strains (KF309698 and KF309699). One sequence obtained from M. glareolus (KU550698) showed a $97 \%$ identity to the sequence of Sarcocystis rodentifelis from a rodent in the Czech Republic (AY015111), Sarcocystis rileyi from a mallard duck (Anas platyrhynchos) from Lithuania (HM185742), Sarcocystis speeri from an opossum (Didelphis virginiana) from Argentina (KT207459), and Sarcocystis sp. from a brown bear (Ursus arctos) from USA (EF564590).

\section{Discussion}

There are only a few studies of piroplasmid parasites associated with ticks and wildlife from Slovakia. This calls for further investigations on the distribution and diversity of piroplasmid species and their relevance to public and animal health in the region. In the present study, questing and rodent-attached ticks, rodents and birds were screened using molecular methods for the presence of Babesia spp. to investigate the vector - host - pathogen associations in the urban/suburban and natural habitats of south-western Slovakia. The study area is characteristic of a sympatric occurrence of $I$. ricinus and $H$. concinna ticks and a great diversity of wildlife [11].

We found $1.5 \%$ of questing I. ricinus and $6.6 \%$ of $H$. concinna ticks to be infected with Babesia parasites. In previous studies from Slovakia, the prevalence of infection with Babesia spp. in questing I. ricinus was similar and varied from 0.4 to $2.7 \%[12,13,19]$ while no reports exist on the presence of piroplasmids in questing $H$. concinna. Generally, Babesia spp. prevalences from 0.4 to $2.7 \%$ have been reported for questing I. ricinus in temperate latitudes of Europe [28, 35-43]. Yet at particular sites 4.6 to $9.6 \%$ of questing I. ricinus were found to be infected with Babesia spp. [17, 44]. Relationships between the prevalence of infection with Babesia spp. of ticks and habitat type could be determined at several sites. Similar to our findings, a significantly higher proportion of Babesia-infected I. ricinus was found in a natural habitat than an urban area in Germany [40], but no Babesia spp. were found in I. ricinus from an urban habitat in the Czech Republic [42]. In contrast to I. ricinus, the overall prevalence of Babesia-infected $H$. concinna from our study was higher in the urban/ suburban habitat than in the natural habitat. We assume that the observed variations in the overall prevalence of infection with Babesia spp. between sites and tick species are associated with the vector competence of ticks for particular species of Babesia and the presence and abundance of competent reservoir hosts.

Babesia microti and B. venatorum as emerging zoonotic species and in some studies also $B$. divergens, have frequently been detected in questing I. ricinus in Europe $[12,17,28,38-40,42,43]$. In previous reports from Slovakia, B. microti was the most common species detected in field-collected $I$. ricinus ticks $[12,19]$. Our results confirmed these observations. The parasite significantly prevailed in ticks from a natural habitat, as has been also reported in a study from Germany [40].

Phylogenetic analysis of partial 18S rRNA gene sequences from our study revealed their identity to those 
of the zoonotic $B$. microti Jena/Germany genotype. Zoonotic $B$. microti genotypes have been found to be associated with microtine rodents and shrews $[45,46]$. In our study, B. microti was the only species detected in rodents and the same $B$. microti strain was also identified in questing and rodent-attached ticks. The overall prevalence of infection in rodents as reported by us is in accordance with previous findings from eastern Slovakia [12]. Prevalence of infection varying from 1.4 up to 27.2 \% was reported for rodents from other European countries [17, 45, 47-51].

Babesia microti-like piroplasmids were previously detected in small mammals from central Europe based on morphological studies of blood and tissue preparations. For example, a $0.4 \%$ prevalence of infection was determined in bank voles (M. glareolus) in former Czechoslovakia [52]. Relatively low proportions of bank voles were found infected by applying molecular methods in the present study $(0.4 \%)$ as well as in eastern Slovakia (1.1\%) [12], although detection rates of blood parasites would be expected to be higher when using molecular methods rather than microscopic examinations [50]. In other central European countries, prevalence of infection with $B$. microti varied in bank voles from 0.0 to $4.9 \%$ $[17,50,51,53]$, whereas 6.1 to $15.9 \%$ of bank voles were found to be infected in Slovenia and Croatia $[45,49]$. In the study at hand, the single B. microti-infected bank vole was positive for blood, but not infested by ticks. Parasite DNA was also detected in the skin of two other bank voles, suggesting local infections.

Previous studies on the yellow-necked mice (A. flavicollis) in central Europe reported a prevalence of $B$. microti infection ranging from 0 to $1.6 \%[17,47,51,53]$ comparable to findings from eastern Slovakia [12] and also to our results. In contrast, higher percentages (11.8 to $16.2 \%)$ of B. microti-infected mice were found in Slovenia and Croatia $[45,49]$.

Voles of the genus Microtus are considered to be the main reservoirs of $B$. microti in natural foci of Europe. Prevalences of infection from 8.3 to $14.3 \%$ were reported for the common vole (M. arvalis) from different European sites $[47,51,53]$. A high proportion of infected common voles $(40.0 \%)$ was also confirmed in our study whereas none or only $0.7 \%$ of the common voles were found to be infected in other sites of Slovakia [12, 52].

The presence of $B$. venatorum, a species recognized as a human pathogen [54], was confirmed in one third of Babesia-positive questing I. ricinus from our study. The occurrence of this parasite in questing ticks has been reported from a few sites of Slovakia only recently $[13,55,56]$. In contrast to $B$. microti infections, the proportion of ticks infected with $B$. venatorum did not differ between the two explored habitats. The roe deer, suggested to be the main reservoir host of this parasite species, [57] is present in both studied habitats. As transovarial transmission of $B$. venatorum has been demonstrated [58], it is probably also maintained in natural foci of Slovakia through its vector tick.

Babesia capreoli/B. divergens accounted for $2.6 \%$ of the Babesia-positive I. ricinus ticks. The B. divergens-like hypervariable $18 \mathrm{~S}$ rRNA gene region analyzed in our study showed identity with those of B. capreoli and $B$. divergens of which $B$. divergens has been demonstrated to be a zoonotic species [59]. Although cattle are considered the principal host of $B$. divergens, infections were also detected in deer assumed to function as reservoir host [60-62]. The presence of B. divergens in I. ricinus was noted once in Slovakia using the Reverse Line Blot Hybridization method [19]. In contrast, B. capreoli, a parasite of roe deer which differs marginally in the $18 \mathrm{~S}$ rRNA gene sequence from $B$. divergens, is unable to infect humans [63]. To our knowledge, there are no published data on the presence of this species in Slovakia.

Babesia odocoilei, known to parasitize American whitetailed deer (Odocoileus virginianus) and to cause babesiosis in cervid and occasionally in bovid species in Europe [62, 64-66], was found in a questing I. ricinus nymph in our study. Related genotypes, e.g. Babesia cf. odocoilei, have been found to infect I. ricinus in Europe $[39,44]$, but their zoonotic potential is unknown.

The presence of B. canis, the most frequent causative agent of canine babesiosis in central Europe, has previously been shown in $D$. reticulatus ticks of Slovakia [20] and also in blood samples from naturally infected dogs [21]. Importantly, we report here for the first time B. canis infection of I. ricinus from Slovakia. Thus, we confirm the previous conjecture of the infection of $I$. ricinus with $B$. canis as noted in a study from Poland $[67,68]$. However, our finding does not allow us to draw conclusions on the competence of $I$. ricinus as a vector of this parasite. We assume the B. canis DNA identified in $I$. ricinus ticks from the urban habitat may have originated from blood meals taken from infected dogs.

In the present study, B. microti-positive engorged I. ricinus ticks were sampled from infected rodents, but the parasite was also detected in a few larvae that fed on uninfected rodent specimens. Interestingly, we also found a few semi-engorged B. microti-positive I. ricinus females attached to rodents, however, it is uncertain if they can complete feeding on these hosts, as they generally prefer medium-sized to large mammalian hosts [69]. Babesia microti-positive $I$. ricinus larvae and nymphs were also found on rodents captured in eastern Slovakia [12] and Switzerland, where the pathogen was detected in xenodiagnostic ticks from infected bank voles [70]. In addition, we detected $B$. microti in a few $H$. concinna ticks feeding on infected rodents and in one larva collected from an 
uninfected yellow-necked mouse. There are no GenBank data on $B$. microti isolates from $H$. concinna and to the best of our knowledge, infection of this tick species by the parasite has not been reported. Babesia microti is thought to be incompetent for transovarial transmission in ticks $[16,71]$ and the positivity of tick larvae might have resulted while feeding on infected hosts or co-feeding with infected ticks. Accordingly, we assume that the positive $H$. concinna larva collected from an uninfected yellownecked mouse acquired the infection via feeding on an infected host and, after interruption, subsequently attached to an uninfected rodent. Our results particularly underline the potential reservoir role of $A$. flavicollis and $M$. arvalis for $B$. microti at our study sites. In addition to $B$. microti, rodent-attached $I$. ricinus infected with $B$. venatorum and $B$. capreoli/B. divergens were found. As vertical transmission has been described for the latter two species of Babesia [7], we assume that these tick specimens acquired the infection from an infected female.

A number of Babesia spp. genetic variants that are closely related to small ruminant piroplasmids, Babesia crassa, Babesia cf. crassa, Babesia motasi, and to the cattleinfecting Babesia major have been found in H. concinna in Europe and Asia [1]. Babesia motasi is known as an agent of mild sheep and goat babesioses in various countries of Europe, Africa and Asia, while B. crassa and B. crassa-like piroplasmids have been detected in sheep blood in Iran and Turkey, and B. major in cattle from Europe and Asia [1]. In the inferred phylogenetic tree, Babesia spp. sequence variants identified in H. concinna from Slovakia clustered in two strongly supported monophyletic clades suggesting that each represents a novel species designated Babesia sp. 1 (Eurasia) and Babesia sp. 2 (Eurasia), respectively. Our results corroborate a wide distribution of these two novel piroplasmid species in $H$. concinna from Europe and Asia supporting recent findings [23, 72]. Their presence across a large area may be related to the broad geographic distribution of $H$. concinna in Eurasia and connection of habitats via longitudinal migration of birds which are known to be preferred hosts of this tick species $[14,15]$.

Piroplasmids of the genus Theileria found in H. concinna in the present study are known to infect a broad spectrum of free-ranging ungulates in neighbouring countries of Slovakia as well as in other regions of Europe $[22,23,73]$. The same or closely related strains of Theileria sp. were found in questing $H$. concinna from Austria [22], Hungary [23] and in rodent-attached and questing $H$. concinna from our study. The presence of Theileria sp. in $H$. concinna from Slovakia indicates that the tick species may be a suitable vector of species of Theileria in this region.

Detection of Hepatozoon spp. and Sarcocystis spp. DNA in rodents support former findings demonstrating that rodents are hosts of a large spectrum of apicomplexan parasites [17]. However, further molecular analyses of the isolates obtained during our study are necessary to reveal their identity with species of Hepatozoon and Sarcocystis.

Birds contribute to the geographic distribution of various tick-borne pathogens and serve as their hosts. Although there are no confirmed infections with Babesia spp. in birds from Europe, B. microti, B. venatorum, and $B$. divergens have been found in ticks infesting birds [71, 74-76]. The occurrence of Babesia spp. in ticks (especially in larvae) from birds suggested that birds may be able to infect ticks, at least in the case of B. microti, a species considered not to be transmitted transovarially. We did not find any Babesia-positive blood sample from birds and thus our results support previous findings that Babesia spp. associated with mammals do not infect birds [18]. Although studies on this topic are lacking, birds may act as carriers for $\mathrm{Ba}$ besia-infected ticks contributing to the dispersal of the parasites in Europe [75, 76].

Co-infections with other microorganisms were detected in less than $0.1 \%$ of the examined Babesia-infected I. ricinus ticks. This result agrees with findings reported from other European countries on co-infection rates depending on the habitat and varying from 0.0 to $1.8 \%$ for Babesia spp. and A. phagocytophilum [17, 35, 68, 77] and from 0.02 to $1.8 \%$ for Babesia spp. and CNM $[78,79]$. The low co-infection rate $(0.05 \%)$ for $\mathrm{Ba}$ besia spp. (with B. microti prevailing) and A. phagocytophilum in ticks reported in this study is not surprising as the two microorganisms seem not to share the same reservoir hosts in the investigated area [26]. In contrast, B. microti and CNM have been found to be associated with rodents [16, 32, 45, 46, 78, 80]. Accordingly, we would have expected to observe higher co-infection rates than determined in ticks $(0.08 \%)$ and rodents $(0.83 \%)$ in the context of this study. Generally, the microbiome of ticks was found to be very complex and rodents can carry a wide variety of microorganisms [81]. Information about the relationships (antagonism, mutualism) between particular microorganisms within the tick and the body of the vertebrate host as well as between microorganisms, ticks and the immune system of the reservoir host are scarce. We assume that the observed co-infection rates are the result of the complexity of the microorganisms - vector - host associations.

\section{Conclusions}

This study employed molecular tools to detect the presence of Babesia spp. in ticks, rodents, and birds from two contrasting habitat types in the Small Carpathian Mountains in south-western Slovakia. Different Babesia spp. were found to be distributed in the tick populations 
of urban/suburban and natural habitats of Slovakia and rodents were found to play an important role as reservoirs of B. microti. Babesia microti and B. venatorum genotypes, identical with respective known zoonotic strains from Europe, dominated in questing and rodent-attached $I$. ricinus. In addition, $B$. capreoli/B. divergens and B. odocoile $i$ were detected in questing $I$. ricinus. The occurrence of these Babesia spp. suggests that ungulates present in the study area may act as their reservoir hosts. Ixodes ricinus may occasionally acquire infection with $B$. canis, probably by feeding on infected dogs. Importantly, we corroborate previous reports of the existence of two novel piroplasmid species referred to as Babesia sp. 1 (Eurasia) and Babesia sp. 2 (Eurasia) which were both identified in questing and rodent-attached $H$. concinna ticks. Our results demonstrate a high diversity of Babesia spp. circulating in $I$. ricinus and $H$. concinna ticks. Important findings of this study are (i) the first detection of $B$. canis and $B$. odocoilei in questing $I$. ricinus, (ii) the detection of two novel species of Babesia, and (iii) the detection of a Theileria sp. in H. concinna in Slovakia. We demonstrate that A. flavicollis and M. arvalis may play a critical role in $B$. microti transmission supporting the hypothesis that the most competent reservoirs are voles of the genus Microtus, particularly M. arvalis. In contrast, M. glareolus seems of secondary importance for the circulation of $B$. microti. Although all studied birds were found to be Babesia-negative, they may represent potential hosts of infected $I$. ricinus and $H$. concinna ticks and thus contribute to the transmission and geographical spread of Babesia spp. Further research is needed to explore the vertebrate hosts of the yet undescribed novel species of Babesia and Theileria infecting $H$. concinna, and to determine their pathogenic potential for humans and animals.

\section{Appendix}

Table 5 Bird species tested for Babesia spp.

\begin{tabular}{ll}
\hline Bird species & Count \\
\hline European green woodpecker (Picus viridis) & 2 \\
Great spotted woodpecker (Dendrocopos major) & 4 \\
European robin (Erithacus rubecula) & 2 \\
Common blackbird (Turdus merula) & 2 \\
Eurasian blackcap (Sylvia atricapilla) & 1 \\
Spotted flycatcher (Muscicapa striata) & 1 \\
Great tit (Parus major) & 25 \\
Eurasian blue tit (Cyanistes caeruleus) & 6 \\
Willow tit (Parus montanus) & 5 \\
Eurasian nuthatch (Sitta europaea) & 9 \\
Common chaffinch (Fringilla coelebs) & 1 \\
\hline
\end{tabular}

\section{Additional file}

Additional file 1: Table S1. Prevalence of Babesia spp. in questing Haemaphysalis concinna per site in 2011-2013. Table S2. Occurence of Babesia spp. in questing Ixodes ricinus in Bratislava and Fúgelka. Table S3. Occurence of Babesia spp. in questing Ixodes ricinus in 2011-2013. Table S4. Occurence of Babesia spp. in questing Ixodes ricinus males, females and nymphs. Table S5. Variables remaining in the best selected model for Babesia microti prevalence in rodents. Table S6. Occurence of Babesia, Candidatus N. mikurensis and Anaplasma phagocytophilum in questing Ixodes ricinus. Table S7. Accession numbers of Apicomplexa 18S rRNA gene sequences (PDF $238 \mathrm{~kb}$ )

\section{Acknowledgments}

The study was funded by EU grant FP7-261504 EDENext and is catalogued by the EDENext Steering Committee as EDENext396 (http://www.edenext.eu). The contents of this publication are the sole responsibility of the authors and do not necessarily reflect the views of the European Commission. Financial support by grant APW DO7RP-0014-11 is also acknowledged. The authors thank Renáta Szalayová and students (Michala Mojšová, Monika Bednáriková, Katarína Mitková, and Erika Vrbová) for help with tick collections, rodent trapping and technical assistance.

\section{Authors' contributions}

MK, EK and ZH designed the study. ZH, LM, LB, EK, MS and MK participated in field work. EK and MK identified ticks and rodents. ZH, LM and LB processed the samples. ZH and LM performed PCR. DH carried out the statistical analyses. ZH, $M K$ and $L S$ analysed the data and wrote the manuscript. DH and LS revised the manuscript. All authors read and approved the final version of the manuscript.

\section{Competing interests}

The authors declare that they have no competing interests.

\section{Declaration}

We declare that the conducted study complies with current laws of the Slovak Republic. There is no conflict of interest with species conservation guidelines. Rodent trapping and handling were approved by the Ministry of Environment of the Slovak Republic, Regional Environmental Office in Bratislava (licence ZPO-594/2012-SAB). Birds were captured, ringed, blood sampled and released under the permission of the Ministry of Environment of the Slovak Republic, No. 9368/2011-2.2.

\section{Author details}

${ }^{1}$ Institute of Zoology, Slovak Academy of Sciences, Dúbravská cesta 9, 84506 Bratislava, Slovakia. ${ }^{2}$ Institute of Biostatistics and Analyses, Faculty of Medicine and Faculty of Science, Masaryk University, Kamenice 3, 62500 Brno, Czech Republic. ${ }^{3}$ Institute of Virology, Biomedical Research Center, Slovak Academy of Sciences, Dúbravská cesta 9, 84505 Bratislava, Slovakia. ${ }^{4}$ Instituto de Patobiología, CICVyA, INTA-Castelar, 1686 Hurlingham, Prov. de Buenos Aires, Argentina. ${ }^{5}$ CONICET (National Research Council of Argentina), C1033AAJ Buenos Aires, Argentina.

Received: 25 February 2016 Accepted: 2 May 2016

Published online: 20 May 2016

\section{References}

1. Schnittger L, Rodriguez AE, Florin-Christensen M, Morrison D. Babesia: A world emerging. Infect Genet Evol. 2012;12:1788-809.

2. Yabsley MJ, Shock BC. Natural history of zoonotic Babesia: Role of wild life reservoirs. Int J Parasitol Parasites Wildl. 2013;2:18-31.

3. Skrabalo Z, Deanovic Z. Piroplasmosis in man: report on a case. Doc Med Geogr Trop. 1957;9:11-6.

4. Hildebrandt A, Gray JS, Hunfeld KP. Human babesiosis in Europe: what clinicians need to know. Infection. 2013;41:1057-72.

5. Mørch K, Holmaas G, Frolander PS, Kristoffersen EK. Severe human Babesia divergens infection in Norway. Int J Infect Dis. 2014;33:37-8.

6. Public Health Authority of the Slovak Republic (http://www.uvzsr.sk/en/). Accessed 4 dec 2015.

7. Hunfeld KP, Hildebrandt A, Gray JS. Babesiosis: recent insights into an ancient disease. Int J Parasitol. 2008;38:1219-37. 
8. Baneth G, Florin Christensen M, Cardoso L, Schnittger L. Reclassification of Theileria annae as Babesia vulpes sp. nov. Parasit Vectors. 2015;8:207.

9. Hildebrandt A, Hunfeld KP, Baier M, Krumbholz A, Sachse S, Lorenzen T, et al. First confirmed autochthonous case of human Babesia microti infection in Europe. Eur J Clin Microbiol Infect Dis. 2007;26:595-601.

10. Gray J, Zintl A, Hildebrandt A, Hunfeld KP, Weiss L. Zoonotic babesiosis: overview of the disease and novel aspects of pathogen identity. Ticks Tick Borne Dis. 2010;1:3-10.

11. Kazimírová M, Hamšíková Z, Kocianová E, Marini G, Mojšová M, Mahríková L, et al. Relative density of host-seeking ticks in different habitat types of south-western Slovakia. Exp Appl Acarol. 2016;69:205-24. doi:10.1007/ s10493-016-0025-6.

12. Blaňarová L, Stanko M, Miklisová D, Víchová B, Mošanský L, Kraljik J, et al. Presence of Candidatus Neoehrlichia mikurensis and Babesia microti in rodents and two tick species (Ixodes ricinus and Ixodes trianguliceps) in Slovakia. Ticks Tick Borne Dis. 2016;7:319-26.

13. Švehlová A, Berthová L, Sallay B, Boldiš V, Sparagano OAE, Špitalská E. Sympatric occurrence of Ixodes ricinus, Dermacentor reticulatus and Haemaphysalis concinna ticks and Rickettsia and Babesia species in Slovakia. Ticks Tick Borne Dis. 2014;5:600-5.

14. Nosek J. The ecology, bionomics and behaviour of Haemaphysalis (Haemaphysalis) concinna tick. Z Parasitenkd. 1971;36:233-41.

15. Hornok S, Kováts D, Csörgő T, Meli ML, Gönczi E, Hadnagy Z, et al. Birds as potential reservoirs of tick-borne pathogens: first evidence of bacteraemia with Rickettsia helvetica. Parasit Vectors. 2014;7:128.

16. Homer MJ, Aguilar-Delfin I, Telford III SR, Krause PJ, Persing DH. Babesiosis. Clin Microbiol Rev. 2000;13:451-69.

17. Silaghi C, Woll D, Hamel D, Pfister K, Mahling M, Pfeffer M. Babesia spp. and Anaplasma phagocytophilum in questing ticks, ticks parasiting rodents and the parasitized rodents - analyzing the host-pathogen vector interface in metropolitan area. Parasit Vectors. 2012;5:191.

18. Hasle G. Transport of ixodid ticks and tick-borne pathogens by migratory birds. Front Cell Infect Microbiol. 2013;3:48.

19. Koči J, Taragel'ová V, Derdáková M, Selyemová D, Cíglerová I, Lenčáková D, et al. Tick seasonal dynamics and prevalence of tick-borne pathogens in Slovakia. In: Špitalská E, Kazimírová M, Kocianová E, Šustek Z, editors. Zborník z Konferencie "Labudove dni". Bratislava: Virologický ústav SAV; 2009. p. 45-7.

20. Duh D, Slovák M, Saksida A, Strašek K, Petrovec M, Avsic Zupanc T. Molecular detection of Babesia canis in Dermacentor reticulatus ticks collected in Slovakia. Biologia (Bratisl). 2006;61:231-3.

21. Chandoga P, Goldová M, Baranová D, Kozák M. First cases of canine babesiosis in the Slovak Republic. Vet Rec. 2002;150:82-4.

22. Fuehrer HP, Biro N, Harl J, Worliczek HL, Beiglböck C, Farkas R, et al. Molecular detection of Theileria sp. ZS TO4 in red deer (Cervus elaphus) and questing Haemaphysalis concinna ticks in Eastern Austria. Vet Parasitol. 2013;197:653-7.

23. Hornok S, Takács N, Kontschán J, György Z, Micsutka A, Iceton S, et al. Diversity of Haemaphysalis-associated piroplasms of ruminants in CentralEastern Europe, Hungary. Parasit Vectors. 2015;8:627.

24. Shock BC, Moncayo A, Cohen S, Michell EA, Williamson PC, Lopez G, et al. Diversity of piroplasms detected in blood-fed and questing ticks from several states in the United States. Ticks Tick Borne Dis. 2014;14:373-80.

25. Paulauskas A, Radzijevskaja J, Mardosaité-Busaitienè D, Aleksandravičienè A Galdikas M, Krikštolaitis R. New localities of Dermacentor reticulatus ticks in the Baltic countries. Ticks Tick Borne Dis. 2015;6:630-5.

26. Svitálková Z, Haruštiaková D, Mahríková L, Berthová L, Slovák M, Kocianová E, et al. Anaplasma phagocytophilum prevalence in ticks and rodents in an urban and natural habitat in South-Western Slovakia. Parasit Vectors. 2015;8:276.

27. Berthová L, Slobodník V, Slobodník R, Olekšák M, Sekeyová Z, Svitálková Z, et al. The natural infection of birds and ticks feeding on birds with Rickettsia spp. and Coxiella burnetii in Slovakia. Exp Appl Acarol. 2016;68:299-314.

28. Casati S, Sager H, Gern L, Piffaretti JC. Presence of potentially pathogenic Babesia sp. for human in Ixodes ricinus in Switzerland. Ann Agric Environ Med. 2006;13:65-70.

29. Edgar RC. MUSCLE: multiple sequence alignment with high accuracy and high throughput. Nucleic Acids Res. 2004;32:1792-7.

30. Kimura M. A simple method for estimating evolutionary rate of base substitutions through comparative studies of nucleotide sequences. J Mol Evol. 1980;16:111-20.

31. Tamura K, Stecher G, Peterson D, Filipski A, Kumar S. MEGA6: molecular evolutionary genetics analysis version 6.0. Mol Biol Evol. 2013;30:2725-9.
32. Hamšíková Svitálková Z, Haruštiaková D, Mahríková L, Mojšová M, Berthová L, Slovák M, et al. Candidatus Neoehrlichia mikurensis in ticks and rodents from urban and natural habitats of South-Western Slovakia. Parasit Vectors. 2016;9:2.

33. Corp IBM. IBM SPSS Statistics for windows, version 22.0. Armonk, NY: IBM Corp; 2013.

34. 34. StatSoft, Inc. STATISTICA (data analysis software system), version 12. 2013. www.statsoft.com. Accessed 2 Feb 2016

35. Reye AL, Hübschen JM, Sausy A, Müller CP. Prevalence and seasonality of tick-borne pathogens in questing lxodes ricinus ticks from Luxembourg. Appl Environ Microbiol. 2010;76:2923-31.

36. Schorn S, Pfister K, Reulen H, Mahling M, Silaghi C. Occurrence of Babesia spp., Rickettsia spp. and Bartonella spp. in Ixodes ricinus in Bavarian public parks, Germany. Parasit Vectors. 2011;4:135.

37. Katargina O, Geller J, Vasilenko V, Kuznetsova T, Järvekülg L, Vene S, et al. Detection and characterization of Babesia species in Ixodes ticks in Estonia. Vector Borne Zoonot Dis. 2011;11:923-8.

38. Egyed L, Elö P, Sréter-Lancz Z, Széll Z, Balogh Z, Sréter T. Seasonal activity and tick-borne pathogen infection rates of Ixodes ricinus ticks in Hungary. Ticks Tick Borne Dis. 2012;3:90-4.

39. Øines $\varnothing$, Radzijevskaja J, Paulauskas A, Rosef O. Prevalence and diversity of Babesia spp. in questing Ixodes ricinus ticks from Norway. Parasit Vectors. 2012;5:156.

40. Overzier E, Pfister K, Thiel C, Herb I, Mahling M, Silaghi C. Diversity of Babesia and Rickettsia species in questing /xodes ricinus: a longitudinal study in urban pasture and natural habitats. Vector Borne Zoonot Dis. 2013;13:559-64.

41. Bonnet S, Michelet L, Moutailler S, Cheval J, Hébert C, Vayssier-Taussat M, et al. Identification of parasitic communities within European ticks using nextgeneration sequencing. PLoS Negl Trop Dis. 2014;8:e2753.

42. Venclikova K, Mendel J, Betasova L, Hubalek Z, Rudolf I. First evidence of Babesia venatorum and Babesia capreoli in questing Ixodes ricinus ticks in the Czech Republic. Ann Agric Environ Med. 2015;22:212-4.

43. Capligina V, Berzina I, Bormane A, Salmane I, Vilks K, Kazarina A, et al. Prevalence and phylogenetic analysis of Babesia spp. in Ixodes ricinus and Ixodes persulcatus ticks in Latvia. Exp Appl Acarol. 2016;68:325-36.

44. Duh D, Petrovec M, Avsic-Zupanc T. Diversity of Babesia infecting European sheep ticks (Ixodes ricinus). J Clin Microbiol. 2001;39:3395-7.

45. Duh D, Petrovec M, Trilar T, Avsic-Zupanc T. The molecular evidence of Babesia microti infection in small mammals collected in Slovenia. Parasitology. 2003;126:113-7.

46. Karbowiak G. Zoonotic reservoir of Babesia microti in Poland. Pol J Microbiol. 2004;53:61-5.

47. Siński E, Bajer A, Welc R, Pawełczyk A, Ogrzewalska M, Behnke JM. Babesia microti: prevalence in wild rodents and Ixodes ricinus ticks from the Mazury Lakes District of North-Eastern Poland. Int J Med Microbiol. 2006;296:137-43.

48. Bown K, Lambin X, Telford GR, Ogden NH, Telfer S, Woldehiwet Z, et al. Relative importance of Ixodes ricinus and Ixodes trianguliceps as vectors for Anaplasma phagocytophilum and Babesia microti in field vole (Microtus agrestis) populations. Appl Environ Microbiol. 2008;74:7118-25.

49. Beck R, Vojta L, Curković S, Mrljak V, Margaletić J, Habrun B. Molecular survey of Babesia microti in wild rodents in central Croatia. Vector Borne Zoonot Dis. 2011;11:81-3.

50. Bajer A, Welc-Falęciak R, Bednarska M, Alsarraf M, Behnke-Borowczyk J, Siński E, et al. Long-term spatiotemporal stability and dynamic changes in the haemoparasite community of bank voles (Myodes glareolus) in NE Poland. Microb Ecol. 2014;68:196-211.

51. Obiegala A, Pfeffer M, Pfister K, Karnath C, Silaghi C. Molecular examinations of Babesia microti in rodents and rodent-attached ticks from urban and sylvatic habitats in Germany. Ticks Tick Borne Dis. 2015;6:445-9.

52. Šebek Z. Blutparasiten der wildlebenden Kleinsäuger in der Tschechoslowakei. Folia Parasit. 1975;22:11-20.

53. Šebek Z, Sixl W, Stünzner D, Valová M, Hubálek Z, Troger H. Zur Kenntnis der Blutparasiten wildlebender Kleinsäuger in der Steiermark und im Burgenland. Folia Parasit. 1980;27:295-301.

54. Herwaldt BL, Cacciò S, Gherlinzoni F, Aspöck H, Slemenda SB, Piccaluga P, et al. Molecular characterization of a non-Babesia divergens organism causing zoonotic babesiosis in Europe. Emerg Infect Dis. 2003;9:943-8.

55. Svitálková Z, Mydlová L, Derdáková M, Taragelová V, Selyemová D, Kocianová E, et al. Prevalencia klieštami prenášaných mikroorganizmov $v$ Ixodes ricinus $v$ urbánnej a sylvatickej oblasti na juhozápadnom Slovensku. In: Hodová I, Přikrylová I, editors. X. České a slovenské parazitologické dny. Program a sborník abstraktů. Brno: Masaryk University; 2012. p. 113. 
56. Víchová B, Haklová B, Pangrácová L, Stanko M, Bona M, Mošanský L, et al. Occurrence of ticks (Ixodida) and tick-borne pathogens in urban areas of Košice city, eastern Slovakia. In: Program and Abstracts. XII International Jena Symposium on Tick Borne Diseases. 2013;p.143. http://www.tbd-symposium. com/media/public/abs_ijstd_xii/P81_Vichova_et_al_edx.pdf. Accessed 15 Feb 2016.

57. Bonnet S, Jouglin M, L'Hostis M, Chauvin A. Babesia sp. EU1 from roe deer and transmission within Ixodes ricinus. Emerg Infect Dis. 2007;13:1208-10.

58. Bonnet S, Brisseau N, Hermouet A, Jouglin M, Chauvin A. Experimental in vitro transmission of Babesia sp. (EU1) by Ixodes ricinus. Vet Res. 2009;40:21.

59. Zintl A, Mulcahy G, Skerrett HE, Taylor SM, Gray JS. Babesia divergens, a bovine blood parasite of veterinary and zoonotic importance. Clin Rev Microbiol. 2003;16:622-36.

60. Duh D, Petrovec M, Bidovec A, Avsic-Zupanc T. Cervids as Babesiae hosts, Slovenia. Emerg Infect Dis. 2005;11:1121-3.

61. Malandrin L, Jouglin M, Sun Y, Brisseau N, Chauvin A. Redescription of Babesia capreoli (Enigk and Friedhoff, 1962) from roe deer (Capreolus capreolus): isolation, cultivation, host specificity, molecular characterisation and differentiation from Babesia divergens. Int J Parasitol. 2010;40:277-84.

62. Zintl A, Finnerty EJ, Murphy TM, de Waal T, Gray JS. Babesias of red deer (Cervus elaphus) in Ireland. Vet Res. 2011;42:7.

63. Malandrin L, Jouglin M, Moreau E, Chauvin A. Individual heterogeneity in erythrocyte susceptibility to Babesia divergens is a critical factor for the outcome of experimental spleen-intact sheep infections. Vet Res. 2009:40:25.

64. Bartlett SL, Abou-Madi N, Messick JB, Birkenheuer A, Kollias GV. Diagnosis and treatment of Babesia odocoilei in captive reindeer (Rangifer tarandus tarandus) and recognition of three novel host species. J Zoo Wildl Med. 2009;40:152-9.

65. Silaghi C, Hamel D, Pfister K, Rehbein S. Babesia species and coinfection with Anaplasma phagocytophilum in free-ranging ungulates from Tyrol (Austria). Tierärztl Mschr Vet Med Austria. 2011;98:268-74.

66. Wiegmann L, Silaghi C, Obiegala A, Karnath C, Langer S, Ternes K, et al. Occurrence of Babesia species in captive reindeer (Rangifer tarandus) in Germany. Vet Parasitol. 2015;211:16-22.

67. Cieniuch S, Stańczak J, Ruczaj A. The first detection of Babesia EU1 and Babesia canis canis in Ixodes ricinus ticks (Acari, Ixodidae) collected in urban and rural areas in northern Poland. Pol J Microbiol. 2009;58:231-6.

68. Stańczak J, Cieniuch S, Lass A, Biernat B, Racewicz M. Detection and quantification of Anaplasma phagocytophilum and Babesia spp. in Ixodes ricinus ticks from urban and rural environment, northern Poland, by realtime polymerase chain reaction. Exp Appl Acarol. 2015;66:63-81.

69. Rizzoli A, Silaghi C, Obiegala A, Rudolf I, Hubálek Z, Földvári G, et al. Ixodes ricinus and its transmitted pathogens in urban and peri-urban areas in Europe: new hazards and relevance for public health. Front Public Health. 2014;2:251.

70. Burri C, Dupasquier C, Bastic V, Gern L. Pathogens of emerging tick-borne diseases, Anaplasma phagocytophilum, Rickettsia spp., and Babesia spp., in ixodes ticks collected from rodents at four sites in Switzerland (Canton of Bern). Vector Borne Zoonot Dis. 2011;11:939-44.

71. Hildebrandt A, Franke J, Meier F, Sachse S, Dorn W, Straube E. The potential role of migratory birds in transmission cycles of Babesia spp., Anaplasma phagocytophilum, and Rickettsia spp. Ticks Tick Borne Dis. 2010;1:105-7.

72. Rar VA, Epikhina TI, Suntsova OV, Kozlova IV, Lisak OV, Pukhovskaya NM, et al. Genetic variability of Babesia parasites in Haemaphysalis spp. and Ixodes persulcatus ticks in the Baikal region and Far East of Russia. Infect Genet Evol. 2014:28:270-5.

73. Galuppi R, Aureli S, Bonoli C, Caffara M, Tampieri MP. Detection and molecular characterization of Theileria sp. in fallow deer (Dama dama) and ticks from an Italian natural preserve. Res Vet Sci. 2011:91:110-5.

74. Hasle G, Leinaas HP, Røed KH, Øines $\varnothing$. Transport of Babesia venatoruminfected Ixodes ricinus to Norway by northward migrating passerine birds. Acta Vet Scand. 2011;53:41

75. Capligina V, Salmane I, Keišs O, Vilks K, Japina K, Baumanis V, et al. Prevalence of tick-borne pathogens in ticks collected from migratory birds in Latvia. Ticks Tick Borne Dis. 2014;5:75-81.

76. Toma L, Mancini F, Di Luca M, Cecere JG, Bianchi R, Khoury C, et al. Detection of microbial agents in ticks collected from migratory birds in central Italy. Vector Borne Zoonot Dis. 2014;14:199-205.

77. Sytykiewicz H, Karbowiak G, Hapunik J, Szpechciński A, Supergan-Marwicz M, Goławska S, et al. Molecular evidence of Anaplasma phagocytophilum and
Babesia microti coinfections in Ixodes ricinus ticks in central-eastern region of Poland. Ann Agric Environ Med. 2012;19:45-9.

78. Silaghi C, Woll D, Mahling M, Pfister K, Pfeffer M. Candidatus Neoehrlichia mikurensis in rodents in an area with sympatric existence of the hard ticks Ixodes ricinus and Dermacentor reticulatus, Germany. Parasit Vectors. 2012;5:285.

79. Coipan EC, Jahfari S, Fonville M, Maassen CB, van der Giessen J, Takken W et al. Spatiotemporal dynamics of emerging pathogens in questing Ixodes ricinus. Front Cell Infect Microbiol. 2013;3:36.

80. Obiegala A, Pfeffer M, Pfister K, Tiedemann T, Thiel C, Balling A, et al. Candidatus Neoehrlichia mikurensis and Anaplasma phagocytophilum: prevalences and investigations on a new transmission path in small mammals and ixodid ticks. Parasit Vectors. 2014;12:563.

81. Diuk-Wasser MA, Vannier E, Krause PJ. Coinfection by Ixodes tick-borne pathogens: Ecological, epidemiological, and clinical consequences. Trends Parasitol. 2016;32:30-42.

\section{Submit your next manuscript to BioMed Central and we will help you at every step:}

- We accept pre-submission inquiries

- Our selector tool helps you to find the most relevant journal

- We provide round the clock customer support

- Convenient online submission

- Thorough peer review

- Inclusion in PubMed and all major indexing services

- Maximum visibility for your research

Submit your manuscript at www.biomedcentral.com/submit
) Biomed Central 